\title{
The Role of Neonatal Sepsis in the Development of Allergic Diseases in Childhood
}

\section{Neonatal Sepsisin Çocukluk Döneminde Allerjik Hastalıkların Gelișimindeki Rolü}

\author{
Seçil Çonkar1, Recep Sancak2, Canan Aygün3 \\ ${ }^{1}$ Ege University Faculty of Medicine, Department of Nephrology, Izmir, Turkey \\ 2 Ondokuz Mayıs University Faculty of Medicine, Department of Allergy, Samsun, Turkey \\ ${ }^{3}$ Ondokuz Mayıs University Faculty of Medicine, Department of Neonatology, Samsun, Turkey
}

\begin{abstract}
Aim: We aimed to demonstrate the effect of neonatal sepsis on the development of allergic diseases at later ages.

Materials and Methods: For the study, 126 children who were diagnosed with sepsis in the neonatal period, and hospitalized between 2001 and 2003 were recruited, and divided into two groups. Group one consisted of children who had sepsis in the neonatal period. Group two children were chosen from among group one's siblings as controls in whom genetic and environmental factors leading to allergic diseases were similar. The prevalence of allergic diseases were compared between the two groups. The Turkish version of the International Study of Asthma and Allergies in Children questionnaire was used via the face-to-face methodology. Additionally, total blood count was studied for potential eosinophilia, total immunoglobulin $E(\mathrm{lgE})$ levels were measured, and skin prick tests were performed on each subject.

Results: Total IgE levels and sensitivity to Dermatophagoides pteronyssinus, Dermatophagoides farinea were significantly lower $(p<0.05)$ in group one. Also the prevalence of asthma and allergic symptoms were significantly less common $(p<0.05)$ in the first group. Interestingly, we found no significant difference in the prevalence of allergic rhinitis and atopic dermatitis between the two groups.

Conclusion: The present study highlighted that contact with severe infections such as sepsis in the neonatal period can be a cause of decreased sensitivity to environmental allergens and the prevalence of asthma in childhood.

Keywords: Allergic rhinitis, asthma, atopic dermatitis, childhood, sepsis neonates, hygiene hypothesis
\end{abstract}

ÖZ

Amaç: Çalışmamızın amacı neonatal sepsisin çocukluk dönemindeki astım, allerjik rinit ve atopik dermatit gelişimi üzerine etkisini araştırmaktır.

Gereç ve Yöntemler: Neonatal dönemde sepsis tanısıyla, 2001-2003 yılları arasında yatıılan 126 çocuk alındı iki gruba ayrıldı. Yenidoğan döneminde sepsis geçiren çocuklar birinci grubu oluşturdu. Ikinci grubu allerjik hastalık gelişiminde etkili olan genetik çevresel faktörlerin benzer olduğu kardeşlerinden oluşturuldu. Iki grupta allerjik hastalık sıkığı açısından karşılaştıııldı. Uluslararası Çocukluk Çağı Astım ve Alerji Çalışması sorularının Türkçe modifikasyonu ailelerle yüz yüze görüşülerek uygulandı. Serum immünoglobulin E (lgE) düzeyi, tam kan, epidermal deri testi yapıldı.

Bulgular: Birinci grubunda ortalama total lgE değerleri ve Dermatophagoides pteronyssinus, Dermatophagoides farinea allerjen duyarlılı̆ı kontrol grubuna göre daha az sıkıkta saptandı $(p<0,05)$. Birinci grupta astım ve astıma bağlı semptomlar kontrol grubuna göre daha az sıklıkta bulundu $(p<0,05)$. Atopik dermatit ve allerjik rinit sıklı̆ı açısından iki grup arasında anlamlı fark bulunmadı.

Sonuç: Erken hayatta sepsis geçiren çocukların kardeşlerine göre erken çocukluk döneminde ev tozu akar allerjen duyarlıı̆̆ı ve astım gelişim sıklığı daha az bulundu.

Anahtar Kelimeler: Allerjik rinit, astım, atopik dermatit, çocukluk, neonatal sepsis, hijyen hipotezi 


\section{Introduction}

Allergic diseases are among the most chronic diseases of childhood and observed with an increasing prevalence worldwide (1). The changes in environmental factors are blamed for such increase (2). Allergic diseases are more common in people living in developed countries and cities than those living in underdeveloped countries and cities (3). Allergic sensitization starts in the intrauterine period. Maternal exposure to allergens during pregnancy is a risk factor for the child to develop an allergic disease. The first year after birth is the most critical period for the development of an allergic disease, which has been shown to be directly related to infections and exposure to endotoxins and allergens during this period (4-6). Among the hypotheses suggested to explain the reason for increasing allergic diseases in recent years, the hygiene hypothesis is the one most commonly discussed and believed to be valid (7). According to the hygiene hypothesis, reduced infectious diseases in a population result in increased allergic diseases. The hygiene hypothesis was first introduced in a study by Dr. Strachan in 1989 by demonstrating a negative correlation between the number of children in a house and hay fever. Strachan suggested that allergic diseases can be prevented through infectious diseases in early childhood (8). Neonatal sepsis is a severe systemic disease developed in the first month of life and caused by pathogen agents invading the blood stream and tissues. Bacterial products such as endotoxins released into the blood are involved in the pathogenesis of neonatal sepsis. Endotoxins are the cellular wall components of $\mathrm{Gr}(-)$ bacteria. Exposure to endotoxins and infectious agents in the early stages of life is believed to prevent the development of atopic diseases (7).

We believe that reduced microbial load in the early period is one of the effective reasons for increased allergic diseases in recent years. In the literature, the effect of neonatal infections on the development of early childhood allergic diseases is controversial. The aim of the present study is to demonstrate the effect of neonatal sepsis on the development of allergic diseases at later ages.

\section{Material and Methods}

This study was conducted at Ondokuz Mayıs University Faculty of Medicine, Pediatric Allergy Department between April and July 2007. The study included patients hospitalized and treated under the diagnosis of sepsis (without prematurity and any other congenital disorders) at Ondokuz Mayıs University Neonatal Infection Service between January 2001 and August 2003, and the siblings of such patients. Sepsis was diagnosed based on the symptoms of poor peripheral circulation, respiratory distress, cyanosis, lethargy, irritability, apneic spells, tachypnea, fever, bradycardia, tachycardia, and poor feeding, in addition to a positive blood culture (9). The study protocol was accepted by the Ethics Committee of our hospital (Decision
No: 2007/32) and informed consent was provided by the parents of the patients before the study. The patient group consisted of 63 children hospitalized and treated under the diagnosis of neonatal sepsis. In the control group there were 63 healthy siblings closest in age. The control group checked to see whether they experienced such severe infectious diseases. If the siblings had undergone severe infection, other siblings were taken into the study. The children included in the study were exposed to a survey, physical examination, blood and stool sampling, epidermal skin test, and pulmonary function test (PFT) required at Ondokuz Mayıs University Children's Hospital, Allergy Polyclinic. First, the parents were asked to answer the questions in a Turkish version of the phase one International Study of Asthma and Allergies in Children (ISAAC) questionnaire. Then all the children were examined thoroughly by a pediatric allergist to manifest the findings of allergic diseases. Complete blood count, and serum total immunoglobulin $\mathrm{E}(\lg \mathrm{E})$ measurements were also done. Hanifin-Rajka diagnostic criteria were used to diagnose atopic dermatitis detected in the examination. Epidermal skin tests were performed by the same person on all the children. The skin tests were performed by using the most common six allergens (SAY \& Stallerjen, France) involving Dermatophagoides farinea (DF), Dermatophagoides pteronyssinus (DP), weed pollen mixture (Chenopodium, Artemisia, Plantago, Salsola Kali), tree pollen mixture (Ulmus, Quercus, Populus, Salix), Alternaria alternata, and Aspergillus fumigatus. Prior to the skin test, the medications recently used by the patients were examined. In the case of antihistamine use within the last ten days, and montelukast one day before, the skin test was postponed to a future date. The skin test was performed using the prick method on the patients' back or the volar of the forearm. Physiological saline solution and histamine hydrochloride $10 \mathrm{mg} / \mathrm{mL}$ were used as negative and positive controls, respectively. Allergen test solutions were dropped for each allergen in such a way that there would be a minimum of $2 \mathrm{~cm}$ between each allergen. The drop site was punctured using a $1 \mathrm{~mm}$ disposable lancet in a way that would not cause bleeding and would not pass beyond the epidermis. The diameter of the induration which occurred 15 minutes later was measured. The test was considered positive when there was no induration in the negative control and the induration caused by the allergen had a diameter $>3 \mathrm{~mm}$. The test was considered negative when there was induration in the negative control and the induration caused by the allergen had a diameter at least $3 \mathrm{~mm}$ greater than the negative control $(10,11)$. A positive reaction to at least one allergen in the epidermal skin tests was considered as atopy (12). Those with detected reaction to allergens were recorded in the survey form. The 0.5 cc-blood samples taken from all the subjects into tubes without anticoagulant were centrifuged to separate serum samples. The samples were kept at $-70{ }^{\circ} \mathrm{C}$ until the study day. From the serum samples, non-specific total IgE levels were studied via immunoassay nephelometric method using 
Dode-Behring (Reagent) kits on the Dode-Behring device at Ondokuz Mayıs University Biochemistry Laboratory. The total IgE values which were greater than the normal valueat-age were considered high. For the age group in the present study, a total $\mathrm{lgE}$ value $\geq 100 \mathrm{IU} / \mathrm{mL}$ was considered high $(13,14)$. Blood samples were taken from all patients into tubes with 2.5-cc anticoagulant. Complete blood count was studied by using Coulter LH 750 at Ondokuz Mayis University Pediatric Hematology Laboratory. The eosinophil count from the complete blood count was evaluated. An eosinophil count $>450$ eosinophil's $/ \mu \mathrm{L}$ blood was defined as eosinophilia (13). Stool samples were taken from all of the children and evaluated for parasitoids in the microbiology laboratory. PFT was scheduled for the cases who showed lower airway obstructive findings at physical examination and who were cooperative. PFT was performed at the allergy unit by using a Flowhandy Zan 100 Spiromed device and Zan GPI 3.00 program. It was performed at constant room temperature in upright position while attached to the device via a mouthpiece and with the nose clamped. In patients with suspected asthma, the parameters such as forced vital capacity (FVC) (L), forced expiratory volume 1 (FEV1) (L/s), FEV1/FVC (\%), peak expiratory flow (L/s), and forced expiratory flow 25-75 (L/s) were assessed by PFT.

\section{Statistical Analysis}

All questionnaire data were analyzed using SPSS (Statistical Package for the Social Sciences) version 16.0 (SPSS Inc.; Chicago, IL, USA). Descriptive statistics were provided for the numeric and categorical variables using mean, standard deviation, and percent distribution where necessary. The values were expressed as mean \pm standard deviation (the lowest-the highest). Mann Whitney $U$ test was used based on the median values for comparisons of nonparametric data between the two independent groups considering the number of patients. Chi-square test was used for the comparison of categorical data, and Fisher Exact test was used for investigating significant differences. A p value of $<0.05$ was considered statistically significant.

\section{Results}

Given the gender distribution of the patient and control groups of the present study, there were $26(41.2 \%)$ females and $37(58.7 \%)$ males in the patient group, while there were $28(44.4 \%)$ females and $35(55.6 \%)$ males in the control group; there was no statistically significant difference in gender between the two groups $(p>0.05)$. The age of the children who constituted the control group ranged from 6 to 10 years and mean age was $91.4 \pm 24.2$ months. The age of the children constituting the patient group ranged from 3 to 6 years and mean age was $67.2 \pm 8.4$ months. There was statistically significant difference in age between the two groups $(p<0.05)$ (Table I). The cases in the patient and control groups were compared for asthma prevalence. Asthma was identified in $4(6.3 \%)$ members of the patient group and
$15(23.8 \%)$ of the control group. There was a statistically significant difference between the two groups $(p<0.05)$. The comparison of allergic disease prevalence in patient and control groups is presented in Table II. Based on the rates of detected allergen sensitivity to DF and DP in the patient and control groups, 4 cases from the patient group had allergen sensitivity to house dust mite compared to 12 cases from the control group. There was a statistically significant difference in allergen sensitivity to house dust mite between the two groups $(p<0.05)$ (Table III).

There was no statistically significant difference in mean eosinophil levels between the two groups. The mean nonspecific total $\mathrm{IgE}$ value was $118.9 \pm 216 \mathrm{IU} / \mathrm{mL}$ in the patient group. The mean total IgE value was $286.7 \pm 424 \mathrm{IU} / \mathrm{mL}$ in the control group. There was a statistically significant difference in mean total IgE levels between the two groups $(p<0.05)$.

\begin{tabular}{|l|l|l|l|}
\hline \multicolumn{4}{|c|}{ Table I. General demographics of patient and control groups } \\
\hline & $\begin{array}{l}\text { Patient group } \\
\text { n (\%) }\end{array}$ & $\begin{array}{l}\text { Control } \\
\text { group n (\%) }\end{array}$ & p \\
\hline Male/Female & $37 / 26$ & $35 / 28$ & $>0.05$ \\
\hline Age (months) & $67.2 \pm 8.4$ & $91.4 \pm 24.2$ & $<0.05$ \\
\hline VD & $33(52.3 \%)$ & $48(76.1 \%)$ & $<0.05$ \\
\hline C/S & $30(47.6 \%)$ & $15(23.8 \%)$ & $<0.05$ \\
\hline Birth weight (g) & $3173 \pm 650$ & $3250 \pm 575$ & $>0.05$ \\
\hline Nursery & $3(4.8 \%)$ & $2(3.2 \%)$ & $>0.05$ \\
\hline Formula & $32(50.8 \%)$ & $17(27 \%)$ & $<0.05$ \\
\hline Breast-feeding & $54(85.7 \%)$ & $53(84.1 \%)$ & $>0.05$ \\
\hline $\begin{array}{l}\text { Duration of breast-feeding } \\
\text { (months) }\end{array}$ & $10.4 \pm 10.4$ & $10.6 \pm 9.7$ & $<0.05$ \\
\hline $\begin{array}{l}\text { VD: Vaginal delivery, C/S: Cesarean section, Normally distributed variables are } \\
\text { expressed in mean } \pm \text { standard deviation }\end{array}$ \\
\hline
\end{tabular}

Table II. Allergic disease prevalence in patient and control groups

\begin{tabular}{|l|l|l|l|}
\hline & $\begin{array}{l}\text { Patient } \\
\text { group }\end{array}$ & $\begin{array}{l}\text { Control } \\
\text { group }\end{array}$ & p \\
\hline Asthma $\mathrm{n}(\%)$ & $4(6.3 \%)$ & $15(23.8 \%)$ & $<0.05$ \\
\hline Allergic rhinitis & $10(15.8 \%)$ & $13(20.6 \%)$ & $>0.05$ \\
\hline Atopic dermatitis & $3(4.8 \%)$ & $5(7.9 \%)$ & $>0.05$ \\
\hline
\end{tabular}

Table III. Epidermal skin test results of patient and control groups

\begin{tabular}{|l|l|l|l|}
\hline & $\begin{array}{l}\text { Patient group } \\
\mathbf{n}(\%)\end{array}$ & $\begin{array}{l}\text { Control group } \\
\mathbf{n}(\%)\end{array}$ & $\mathbf{p}$ \\
\hline DF+DP & $2(3.2 \%)$ & $11(17.4 \%)$ & $<0.05$ \\
\hline DP+DF+Mix tree pollen & $2(3.2 \%)$ & - & $>0.05$ \\
\hline Alternaria alternata & $1(1.6 \%)$ & $2(3.2 \%)$ & $>0.05$ \\
\hline DF+DP+Aspergillus fumigatus & - & $1(1.6 \%)$ & $>0.05$ \\
\hline Mix weed pollen & $2(3.2 \%)$ & $1(1.6 \%)$ & $>0.05$ \\
\hline DP: Dermatophagoides pteronyssinus, DF: Dermatophagoides farinea \\
\hline
\end{tabular}




\section{Discussion}

Allergic diseases, especially asthma, atopic dermatitis, and allergic rhinitis are the most common chronic diseases during childhood (15). The asthma prevalence has been shown to increase dramatically worldwide, specifically within the last 20-30 years (16). According to the hygiene hypothesis, childhood infections prevent the development of allergic diseases (17). Allergic diseases occur after the Th-2 immune response to common environmental allergens due to genetic predisposition $(18,19)$. The Th-1/Th-2 balance is based on genetic factors, contact with environmental allergens, and microbial exposure in the early period. The joint increase in diseases related to Th-1 and Th-2 is believed to result from the effect of T-regulator cells (18). Allergic sensitization starts at the prenatal period (20). The development of allergic diseases has been observed as directly related to certain factors such as the amount of allergens contacted in the first year of life, previous infections, endotoxin exposure, and the bacterial density of intestinal flora (21). Michel et al. (22) showed that asthma symptoms are triggered by endotoxin exposure by inhalation. The present study found a lower prevalence of early childhood asthma in children with previous neonatal sepsis compared to their siblings. The cases in our control group had the same environmental and genetic risk factors for allergic diseases. For this reason, we believe that microbial endotoxin exposure due to neonatal sepsis or other factors that we could not demonstrate might be influential. Other studies in the literature similar to the present study were reviewed. The study by Ryozawa et al. (23) evaluated children with and without neonatal sepsis in terms of allergic disease development at the age of four. The authors formed the control and patient groups with children who had different genetic and environmental factors. In our country, a similar study by Cetinkaya et al. (24) compared the prevalence of allergic diseases between 85 children with previous neonatal sepsis, and their siblings. The ISAAC questionnaire form, $\lg \mathrm{E}$ levels and skin tests for aeroallergens were used. This study is similar to the present study in that it had a control group consisting of siblings with the same environmental and genetic factors. The study by Cetinkaya et al. (24) reported the mean age of the patient group as being $48.6 \pm 12.85$ months. In the present study, the mean age of the patient group was $67.2 \pm 8.4$ months and our patient group included children older than those in the study by Cetinkaya et al. (24). It is known that children develop allergic diseases first at the age of 4-5 at a rate of $80-90 \%$ (13). Considering that allergic diseases are not completely manifested at an early age, the study by Cetinkaya et al. (24) included children younger than 4-5 years of age. Cetinkaya et al. (24) established that the asthma prevalence was $3.5 \%$ in children with previous neonatal sepsis and $11.8 \%$ in their siblings. In the present study, the asthma prevalence was $6.3 \%$ in children with previous sepsis and $23.8 \%$ in the control group. Similar to the study by Cetinkaya et al. (24), the present study found less frequent asthma development in children with previous neonatal sepsis compared to their siblings. The present study serves as a preliminary to evaluating the effect of neonatal sepsis on the development of childhood allergic diseases, especially within the first six years. This study has increased reliability as the control group consists of siblings with the same genetic and environmental factors, a higher mean age of the patient group, face-to-face completion of the questionnaire form, and performance of a physical examination by an allergist with regard to allergic diseases. The present study established a negative relationship between neonatal sepsis and asthma development and sensitivity to house dust mite until the age of 6. Neonatal sepsis was not related to the development of other allergic diseases. We believe that this may result from early endotoxin exposure and/or other factors that have not been determined yet.

\section{Conclusion}

In conclusion, the present study found that children who have been hospitalized for sepsis in the neonatal period develop sensitivity to some allergens and asthma less frequently than their siblings who have not encountered neonatal sepsis. It seems that neonatal sepsis is likely to contribute to the prevention of asthma development and sensitization to some environmental allergens through some mechanisms acting on the innate immune system during its maturation.

\section{Ethics}

Ethics Committee Approval: The study protocol was accepted by the Ethics Committee of our hospital (Decision No: 2007/32), Informed Consent: Consent form was filled out by all participants.

Peer-review: Internally peer-reviewed.

\section{Authorship Contributions}

Surgical and Medical Practices: Seçil Çonkar, Concept: Recep Sancak, Design: Recep Sancak, Data Collection or Processing: Canan Aygün, Analysis or Interpretation: Seçil Çonkar, Literature Search: Seçil Çonkar, Writing: Seçil Çonkar.

Conflict of Interest: No conflict of interest was declared by the authors.

Financial Disclosure: The authors declared that this study received no financial support.

\section{References}

1. Beasley R, Crane J, Lai CK, Pearce N. Prevalence and etiology of asthma. J Allergy Clin Immunol 2000;105:46672.

2. Xuan W, Marks GB, Toelle BG, et al. Risk factors for onset and remission of atopy, wheeze, and airway hyperresponsiveness. Thorax 2002;57:104-9.

3. Worldwide variation in prevalence of symptoms of asthma, allergic rhinoconjunctivitis, and atopic eczema: ISAAC. The International Study of Asthma and Allergies in Childhood (ISAAC) Steering Committee. Lancet 1998;351:1225-32. 
4. Gehring $U$, Bolte $\mathrm{G}$, Borte $\mathrm{M}$, et al. Exposure to endotoxin decreases the risk of atopic eczema in infancy: a cohort study. J Allergy Clin Immunol 2001;108:847-54.

5. Herz U, Petschow B. Perinatal events affecting the onset of allergic diseases. Curr Drug Targets Inflamm Allergy 2005;4:523-9.

6. Bellanti JA, Kadlec JV, Escobar-Gutierrez A. Cytokines and the immune response. Pediatr Clin North Am 1994;41:597621.

7. Yoo J, Tcheurekdjian H, Lynch SV, Cabana M, Boushey HA. Microbial manipulation of immune function for asthma prevention: inferences from clinical trials. Proc Am Thorac Soc 2007; 4:277-82.

8. Strachan DP. Hay fever, hygiene, and household size. BMJ 1989;299:1259-60.

9. Berner R, Niemeyer CM, Leititis JU, et al. Plasma levels and gene expression of granulocyte colony-stimulating factor tumor necrosis factor-alpha, interleukin (IL)-1 beta, IL-6, IL-8, and soluble intercellular adhesion molecule-1 in neonatal early onset sepsis. Pediatr Res 1998:44:469-77.

10. Van Asperen PP, Kemp AS, Mellis CM. Skin test reactivity and clinical allergen sensitivity in infancy. J Allergy Clin Immunol 1984;73:381-6.

11. Demoly P, Michel FB, Bousquet J. Invivo methods for study of allergy skin tests, techniques and interpretation. In: Middleton EJ, Reed CE, Ellis EF, Adkinson NF Jr, Yunginger JW, Busse W (eds). Allergy: Principles and Practice, 5th ed, St Louis, Mosby Year Book, 1998. p. 433.

12. Murray CS, Woodcock A, Smillie Fl, et al. Tobacco smoke exposure, wheeze, and atopy. Pediatr Pulmonol 2004;37:4928.

13. Sly MR. Allergic disorders. In: Behrman RE, Kliegman RM, Arvin AM (eds). Nelson Textbook of Pediatrics, Philedelphia 2000. p. 614-8.
14. Burney P, Malmberg E, Chinn S, Jarvis D, Luczynska C, Lai $\mathrm{E}$. The distribution of total and specific serum $\lg E$ in the European Community Respiratory Health Survey. J Allergy Clin Immunol 1997;99:314-22.

15. Global Initiative for Asthma. Global strategy for management and prevention revised. Medical Communications Resources, Inc. NIH publication 2006.

16. Halken S. Prevention of allergic disease in childhood: clinical and epidemiological aspects of primary and secondary allergy prevention. Pediatr Allergy Immunol 2004;15(Suppl 16):4-5.

17. Yazdanbakhsh M, Kremsner PG, van Ree R. Allergy, parasites, and the hygiene hypothesis. Science 2002;296:490-4.

18. Stone KD. Atopic diseases of childhood. Curr Opin Pediatr 2002;14:634-46.

19. van der Velden VH, Laan MP, Baert MR, de Waal Malefyt $R$, Neijens HJ, Savelkoul HF. Selective development of a strong Th2 cytokine profile in high-risk children who develop atopy: risk factors and regulatory role of IFN-gamma, IL-4 and IL-10. Clin Exp Allergy 2001;31:997-1006.

20. Björkstein B, Kjellman B, Zeiger RS. Development and prevention of allergic disease in chilhood. In: Middleton E, Reed CE, Ellis EF, Adkinson FN, Yunginger JW, WW B (eds). Allergy: principles and practice. 5th ed. St Louis, Mosby, 1998. p.816-87.

21. Warner JA, Warner JO. Early life events in allergic sensitisation. Br Med Bull 2000;56:883-93.

22. Michel O, Kips J, Duchateau J, et al. Severity of asthma is related to endotoxin in house dust. Am J Respir Crit Care Med 1996;154:1641-6.

23. Ryozawa M, Matsubara T, Ichiyama T, Umeda K, Furukawa S. Clinical sepsis in neonates is responsible for the lower prevalence of developing allergy. Pediatr Int 2007;49:15-8.

24. Cetinkaya F, Uslu HS, Nuhoglu A. Effect of neonatal sepsis on the development of allergies and asthma in later childhood. Int Arch Allergy Immunol 2007;142:145-50. 